EPJ Web of Conferences 24, 05010 (2012)

DOI: $10.1051 /$ epjconf/20122405010

(c) Owned by the authors, published by EDP Sciences - SIF, 2012

\title{
Natural radioactivity levels (K, Th and Ra) in some areas of Punjab, India
}

\author{
Arvind D. Sabharwal*, Bhupinder Singh, Sanjeev Kumar and \\ SURINDER SingH
}

\author{
Department of Physics, Guru Nanak Dev University
}

Amritsar, India

\begin{abstract}
Radioactivity, natural and man-made, is omnipresent in the earth's crust in different amounts. Natural radioactive materials under certain conditions can reach hazardous radiological levels. So, it becomes necessary to study the natural radioactivity levels in soil to assess the dose for the population in order to know the health risks and to have a baseline for future changes in the environmental radioactivity due to human activities. ${ }^{226} \mathrm{Ra},{ }^{232} \mathrm{Th}$ and ${ }^{40} \mathrm{~K}$ analysis has been carried out in soil samples collected from some areas of Punjab, India using gamma-ray spectrometry. The technique of gamma ray spectrometry was applied using high purity germanium gamma-ray detector and a PC based MCA. Radium equivalent activities are calculated for the analyzed samples to assess radiation hazards arising due to the use of these soil samples in construction of dwellings. The measured activity in the soil ranges from 23.17 to $57.87 \mathrm{~Bq} \mathrm{~kg}^{-1}, 59.03$ to $160.40 \mathrm{~Bq} \mathrm{~kg}^{-1}$ and 228.06 to $501.03 \mathrm{~Bq} \mathrm{~kg}^{-1}$ for ${ }^{226} \mathrm{Ra},{ }^{232} \mathrm{Th}$ and ${ }^{40} \mathrm{~K}$ with mean values of $37.93,84.47$ and $351.17 \mathrm{~Bq} \mathrm{~kg}^{-1}$ respectively. It has been observed that on the average the outdoor terrestrial gamma air absorbed dose rate is about $84.65 \mathrm{nGy} \mathrm{h}^{-1}$.
\end{abstract}

*E-mail: arvinddeepaksabharwal@yahoo.com; arvindsabharwal1976@gmail.com

This is an Open Access article distributed under the terms of the Creative Commons Attribution License 2.0, which permits unrestricted use, distribution, and reproduction in any medium, provided the original work is properly cited. 


\section{Introduction}

The world is naturally radioactive, and around $90 \%$ of human radiation exposure arises from natural sources such as cosmic radiations, exposure to radon gas, and terrestrial radiations. Natural radionuclides in rocks and soil generate a significant component of the background radiation exposure to human beings, which depend on the composition of the soils and rocks in which they are contained. A significant contribution to total dose from natural sources comes from terrestrial radionuclides such as ${ }^{238} \mathrm{U},{ }^{232} \mathrm{Th}$ and ${ }^{40} \mathrm{~K}$ present in soil (Khan et al. 1998; Menon et al. 1982; Turhan et al. 2008). Since these radionuclides are not uniformly distributed, the knowledge of their distribution in soil and rocks plays an important role in radiation protection and measurement (Khan et al. 1994). The radiation dose comes from gamma-rays, which are emitted from rocks, soil and some building materials composed of the earth's crust. The estimation of exposures of humans to the various sources of radiation is important. Some of the exposures are fairly constant and uniform for all individuals everywhere for example, the dose from ingestion of ${ }^{40} \mathrm{~K}$ in food. As radiation of natural origin is responsible for most of the total radiation exposure, knowledge of the dose received from natural sources is very important for not only of its effects on health but also of the incidence of other radiation from man-made sources (UNSCEAR 2000). The nuclides having half-life comparable with the age of earth or their corresponding decay products, existing in terrestrial materials, such as ${ }^{40} \mathrm{~K},{ }^{238} \mathrm{U}$ and ${ }^{232} \mathrm{Th}$ radionuclides are of great interest.

Most of the developed and developing countries in the world are carrying out nation-wide surveys to assess the amount of radioactivity in order to establish possible radiological hazards and to take safety measures if necessary (Beretka and Mathew, 1985; Mollah et al., 1986; Paredes et al., 1987; Nazaro and Nero, 1988). Naturally occurring radionuclides of terrestrial origin (primordial nuclides) are present in various degrees in all media in the environment, including the human body. There have been many surveys to determine the background levels of the radionuclides in soils like igneous, granite and sedimentary. All of these measurements indicate that gamma-emitting radionuclides in ${ }^{226} \mathrm{Ra},{ }^{232} \mathrm{Th}$ series and ${ }^{40} \mathrm{~K}$, made approximately equal contributions to the externally incident gamma radiation dose to individuals in typical situations both indoor and outdoor. The present study was undertaken to measure the specific activity and the gamma-ray absorbed dose of naturally occurring radionuclides $\left({ }^{226} \mathrm{Ra},{ }^{232} \mathrm{Th}\right.$ and $\left.{ }^{40} \mathrm{~K}\right)$ in soil samples of some areas of Punjab, India using gamma-ray spectrometry as it provides a fast and simple method of measuring the concentration 


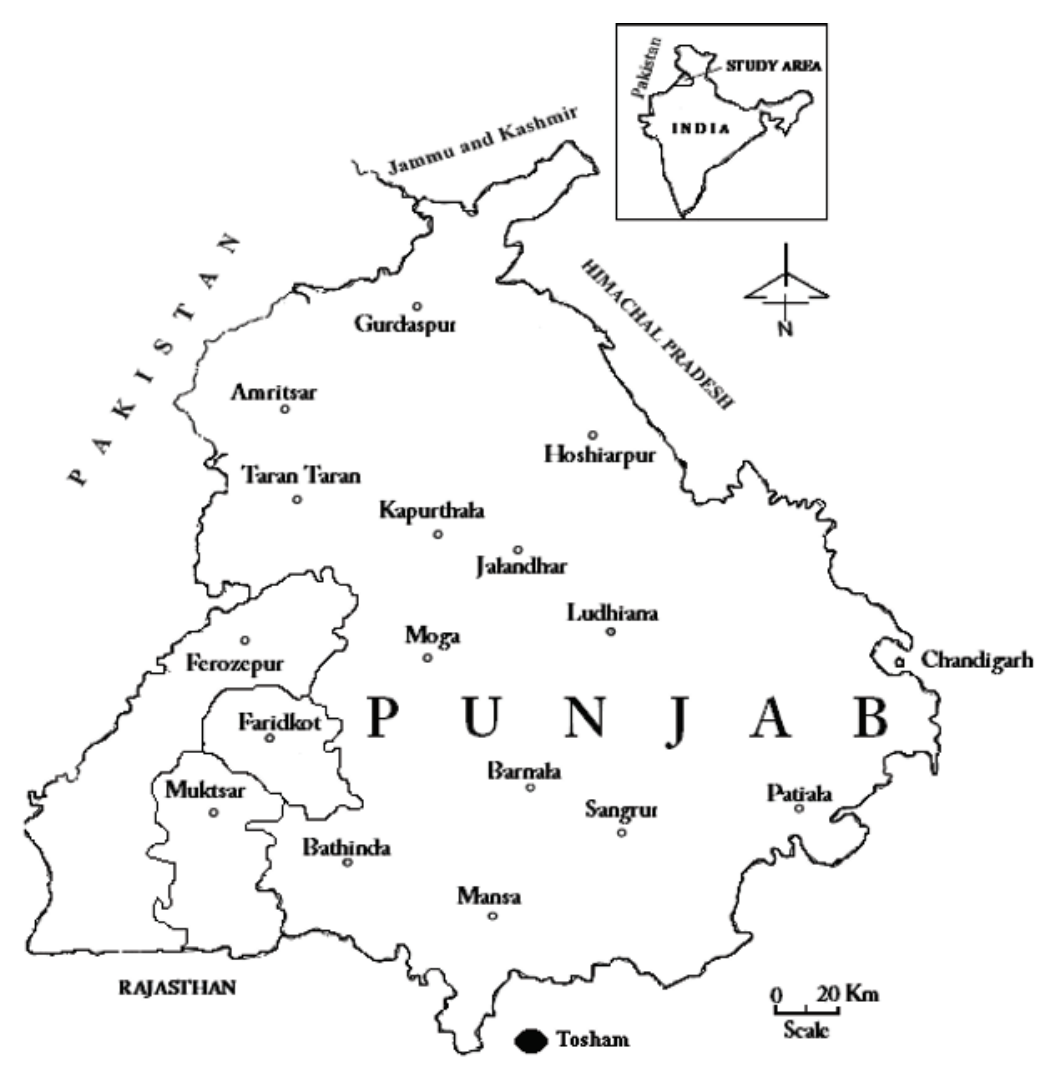

Figure 1: Map showing the area surveyed.

of natural and manmade radionuclides into the environment. The multi elemental and non-destructive character of this technique makes it superior over the other traditional techniques.

\section{Geology of the area}

Punjab state extends from the latitudes $29.30^{\circ}$ to $32.32^{\circ}$ North and longitudes $73.55^{\circ}$ to $76.50^{\circ}$ east. It is bounded on the west by Pakistan, on the north by Jammu and Kashmir, on the northeast by Himachal Pradesh and on the south by Haryana and Rajasthan. Due to the presence of a large number of rivers, most of the Punjab is a fertile plain. The southeast region of the state is semi-arid and gradually presents a desert landscape. A belt of undulating hills extends along the northeastern part of the state at the 
foot of the Himalayas. The soil characteristics are influenced to a very limited extent by the topography, vegetation and parent rock. The variation in soil profile characteristics is much more pronounced because of the regional climatic differences. On the basis of soil types Punjab can be divided into three distinct regions; southwestern, central, and eastern. Southwestern Punjab, India, has been taken as region of interest in the present work. Our studies area consists of three districts of Punjab viz. Faridkot, Ferozepur and Muktsar (fig. 1).

Muktsar, with an area of $2615 \mathrm{~km}^{2}$, which constitutes $5.19 \%$ of the area of Punjab, is situated in the southwestern zone of Punjab. It lies between $30^{\circ} 69^{\prime}$ and $29^{\circ} 87^{\prime}$ latitude and $74^{\circ} 21^{\prime}$ and $74^{\circ} 86^{\prime}$ longitude. It is bounded by the States of Rajasthan and Haryana in the South, district Faridkot in North, Ferozepur in West and Bathinda in the East.

Faridkot is situated between $29^{\circ} 54^{\prime}$ to $30^{\circ} 54^{\prime}$ latitude and $74^{\circ} 15^{\prime}$ to $75^{\circ} 25^{\prime}$ longitude. It lies in the southwest of the state and is surrounded by Ferozepur District in the northwest, Moga and Ludhiana Districts in the northeast and districts of Bathinda and Sangrur in the south. The District covers an area of $1469 \mathrm{~km}^{2}$, which is $2.92 \%$ of the total area of the State and accommodates a population of $5,52,466$ which is $2.27 \%$ of the total population of the state.

The Ferozpur District lies between latitude $29^{\circ} 55^{\prime}$ and $31^{\circ} 09^{\prime}$ and between longitude $73^{\circ} 53^{\prime}$ and $75^{\circ} 24^{\prime}$. On the northeast, the river Satluj generally separates it from the Jalandhar and Kapurthala districts. The united stream of the Satluj and the Beas generally separates it from the Amritsar District in the northwest, and farther down from the Pakistan, with the exception of some areas on each side of the river.

\section{Experimental procedure}

\subsection{Measurement of natural radioactivity}

In order to measure the natural radioactivity in soil, surface soil samples were collected from different locations from three shown districts of Punjab, India namely Faridkot, Ferozepur and Muktsar. One sample from each location was collected by digging a hole at a depth of $0.5 \mathrm{~m}$ in the ground surface. After collection, samples were crushed to fine powder by using mortar and pestle. Fine quality of the sample was obtained using a scientific sieve of 100 micron-mesh size. Before measurement, samples were dried, packed, sealed in an airtight PVC container and kept for about 4 weeks to allow radioactive equilibrium between radon $\left({ }^{222} \mathrm{Ra}\right)$ and its short-lived decay products. An 
average $0.25 \mathrm{~kg}$ of soil was used per sample. Using high purity germanium (HPGe) detectors based on a high-resolution gamma spectrometry system, the activity of soil samples was determined. The details of the technique are the same as reported elsewhere (Mehra et al., 2007). The efficiency calibration for the system was carried out using secondary standards of uranium ore in the same geometry as for the sample counting. The secondary standard was calibrated with the primary standard (RGU-1) obtained from the International Atomic Energy Agency. Gamma transitions of $186 \mathrm{keV}$ and $609 \mathrm{keV}$ were used for ${ }^{226} \mathrm{Ra}, 1461 \mathrm{keV}$ for ${ }^{40} \mathrm{~K}, 338,463,911,968 \mathrm{keV}$ for ${ }^{228} \mathrm{Ac}, 727 \mathrm{keV}$ of ${ }^{212} \mathrm{Bi}$, and $238 \mathrm{keV}$ of ${ }^{212} \mathrm{~Pb}$ for ${ }^{232} \mathrm{Th}$ for the laboratory measurement of the respective activity concentration. The samples were counted for a period of $72,000 \mathrm{~s}$ each. A typical spectrum is shown in fig. 2. Based on the applied conditions, the achieved detection limits were $2 \mathrm{~Bq} \mathrm{~kg}^{-1}, 3 \mathrm{~Bq} \mathrm{~kg}^{-1}$ and $2 \mathrm{~Bq} \mathrm{~kg}^{-1}$ for ${ }^{226} \mathrm{Ra}^{2}{ }^{232} \mathrm{Th}$ and ${ }^{40} \mathrm{~K}$, respectively. The concentration of radionuclides was calculated using the following equation

$$
\operatorname{Activity}(\mathrm{Bq})=\frac{\mathrm{CPS} \times 100 \times 100}{\text { B.I. } \times \mathrm{Eff}} \pm \frac{\mathrm{SD}_{\mathrm{CPS}} \times 100 \times 100}{\text { B.I. } \times \mathrm{Eff}}
$$

where, $\mathrm{CPS}=$ Net count rate per second

B.I. = Branching ratio Intensity, and

$\mathrm{Eff}=$ full peak efficiency of the detector.

\subsection{Radium equivalent activity}

The radium equivalent activity was calculated through the following relation (Yu et al., 1992)

$$
\mathrm{Ra}_{\mathrm{eq}}=C_{\mathrm{Ra}}+1.43 C_{\mathrm{Th}}+0.07 C_{\mathrm{K}}
$$

where $C_{\mathrm{Ra}}, C_{\mathrm{Th}}$ and $C_{\mathrm{K}}$ is the respective activity concentration of ${ }^{226} \mathrm{Ra}$, ${ }^{232} \mathrm{Th}$ and ${ }^{40} \mathrm{~K}$ in $\mathrm{Bq} \mathrm{kg}^{-1}$. While defining the Raeq activity, it has been assumed that $370 \mathrm{~Bq} \mathrm{~kg}^{-1}{ }^{226} \mathrm{Ra}$ or $259 \mathrm{~Bq} \mathrm{~kg}^{-1}{ }^{232} \mathrm{Th}$ or $4810 \mathrm{~Bq} \mathrm{~kg}^{-1}{ }^{40} \mathrm{~K}$ produce the same gamma dose rate. The radium equivalent activity ( $\left.\mathrm{Ra}_{\mathrm{eq}}\right)$ in these soil samples ranges from $136 \mathrm{~Bq} \mathrm{~kg}^{-1}$ in Faridkot to $310 \mathrm{~Bq} \mathrm{~kg}^{-1}$ in Sitoguno with a mean value of $183 \mathrm{~Bq} \mathrm{~kg}^{-1}$ which is less than the safe limit $\left(370 \mathrm{~Bq} \mathrm{~kg}^{-1}\right)$ recommended by the Organization for Economic Cooperation and Development (OECD), (1979).

\subsection{Calculation of annual effective dose}

Annual estimated average effective dose equivalent received by the population was calculated using a conversion factor of $0.7 \mathrm{~Sv} \mathrm{~Gy}^{-1}$, which was 


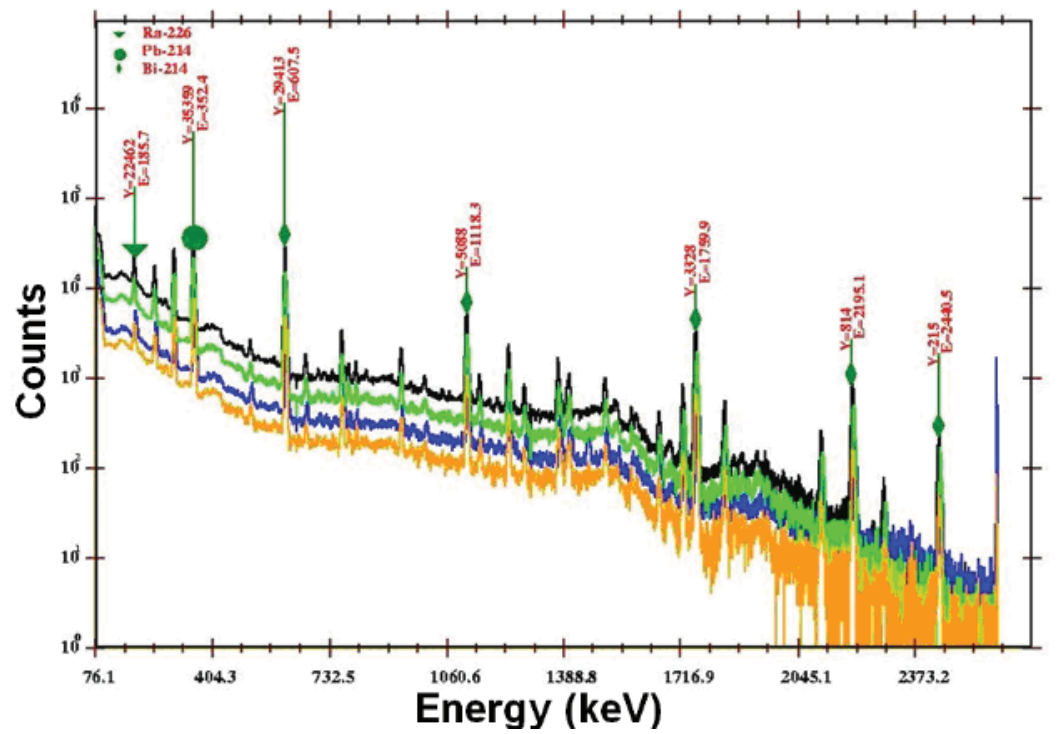

Figure 2: Gamma-ray spectra of samples showing various peaks of radionuclides.

used to convert the absorbed rate to human effective dose equivalent with an outdoor occupancy of $20 \%$ and $80 \%$ for indoors (UNSCEAR, 1993). The annual effective doses were determined as follows

$$
\begin{aligned}
\operatorname{Indoor}(\mathrm{nSv})= & (\text { Absorbed dose }) \mathrm{nGyh}^{-1} \times 8760 \mathrm{~h} \\
& \times 0.8 \times 0.7 \mathrm{SvGy}^{-1} \\
\text { Outdoor }(\mathrm{nSv})= & (\text { Absorbed dose }) \mathrm{nGyh}^{-1} \times 8760 \mathrm{~h} \\
& \times 0.2 \times 0.7 \mathrm{SvGy}^{-1},
\end{aligned}
$$

\subsection{External hazard index $\left(H_{\mathrm{ex}}\right)$}

The external hazard index $H_{\mathrm{ex}}$ can be calculated using the following equation (Beretka and Mathew, 1985)

$$
H_{\mathrm{ex}}=\frac{C_{\mathrm{Ra}}}{370}+\frac{C_{\mathrm{Th}}}{259}+\frac{C_{\mathrm{K}}}{4810} \leq 1,
$$

where $C_{\mathrm{Ra}}, C_{\mathrm{Th}}$ and $C_{\mathrm{K}}$ is the activity concentration of ${ }^{226} \mathrm{Ra},{ }^{232} \mathrm{Th}$ and ${ }^{40} \mathrm{~K}_{\text {in }} \mathrm{Bq} \mathrm{kg}^{-1}$, respectively. If the value of this index is less than unity, the radiation hazard is insignificant. The maximum value of $H_{\text {ex }}$ equal to unity corresponds to the upper limit of $\mathrm{Ra}_{\mathrm{eq}}\left(370 \mathrm{~Bq} \mathrm{~kg}^{-1}\right)$. 


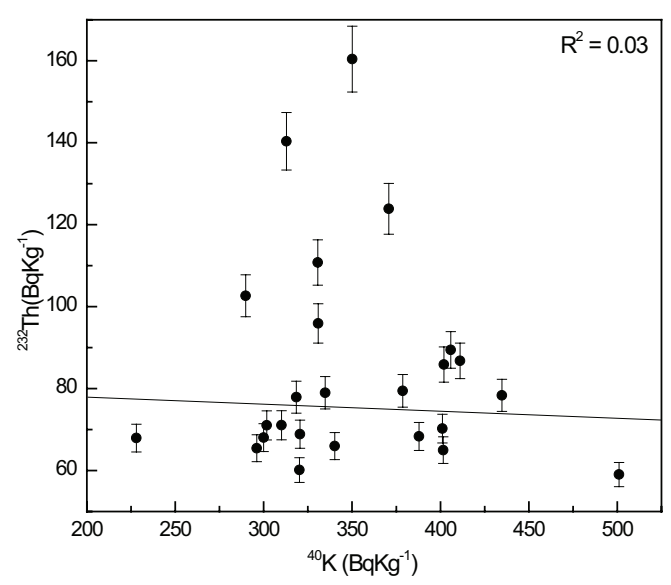

Figure 3: Variation of ${ }^{232} \mathrm{Th}$ with ${ }^{40} \mathrm{~K}$ activity concentrations in the soils of the investigated area.

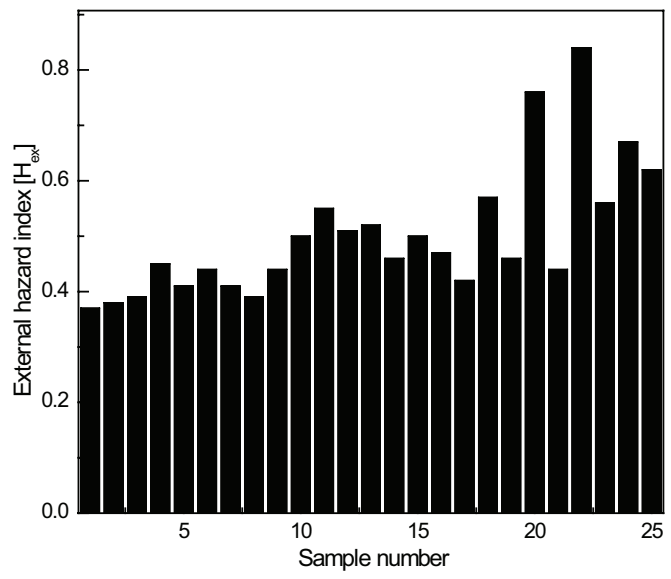

Figure 4: Bar diagram showing the values of the external hazard index at different locations in Punjab. 
Table 1: Analytical results for the activity concentration of ${ }^{226} \mathrm{Ra},{ }^{232} \mathrm{Th}$ and of ${ }^{40} \mathrm{~K}\left(\mathrm{~Bq} \mathrm{~kg}^{-1}\right)$ determined for each of the measured samples together with their total uncertainties, radium equivalent, external hazard index, total absorbed dose and effective dose rate at various locations of Northern Punjab, India.

\begin{tabular}{|c|c|c|c|c|c|c|c|c|c|}
\hline \multirow[t]{2}{*}{$\begin{array}{l}\text { S. } \\
\text { No }\end{array}$} & \multirow[t]{2}{*}{$\begin{array}{l}\text { Sample } \\
\text { Location }\end{array}$} & \multirow{2}{*}{\begin{tabular}{|c|} 
Radium \\
Concentration \\
in Soil \\
$\mathrm{C}_{\text {Radium }}$ \\
$\left(\mathrm{Bq} \mathrm{kg}^{-1}\right)$
\end{tabular}} & \multirow{2}{*}{$\begin{array}{c}\text { Thorium } \\
\text { Concentration } \\
\text { in Soil } \\
\mathrm{C}_{\text {Thorium }} \\
\left(\mathrm{Bq} \mathrm{kg}^{-1}\right)\end{array}$} & \multirow{2}{*}{$\begin{array}{c}\text { Potassium } \\
\text { Concentration } \\
\text { in Soil } \\
\mathrm{C}_{\text {Potassium }} \\
\left(\mathrm{Bq} \mathrm{kg}^{-1}\right)\end{array}$} & \multirow[t]{2}{*}{$\begin{array}{c}\text { Radium } \\
\text { Equivalent }\end{array}$} & \multirow[t]{2}{*}{$\begin{array}{c}\text { Absorbed } \\
\text { Dose } \\
\left(\mathrm{nGy} \mathrm{h}^{-1}\right)\end{array}$} & \multicolumn{2}{|c|}{$\begin{array}{c}\text { Annual } \\
\text { effective } \\
\text { dose } \\
(\mathrm{mSv})\end{array}$} & \multirow[t]{2}{*}{$\begin{array}{c}\text { External } \\
\text { Hazard } \\
\text { Index } \\
\left(H_{\text {ex }}\right)\end{array}$} \\
\hline & & & & & & & Indoor & Outdoor & \\
\hline 1 & Faridkot & 23.17 & 67.92 & 228.00 & 136.26 & 62.43 & 0.31 & 0.08 & 0.37 \\
\hline 2 & Sadik & 24.12 & 65.45 & 296.14 & 138.44 & 64.15 & 0.31 & 0.08 & 0.38 \\
\hline 3 & $\begin{array}{c}\text { Kot } \\
\text { Kapura }\end{array}$ & 34.23 & 60.12 & 320.23 & 142.62 & 66.49 & 0.33 & 0.08 & 0.39 \\
\hline 4 & Khara & 40.9 & 71.06 & 310.12 & 164.22 & 75.96 & 0.37 & 0.09 & 0.45 \\
\hline 5 & Jaito & 28.23 & 68.87 & 320.56 & 149.15 & 69.19 & 0.34 & 0.08 & 0.41 \\
\hline 6 & $\begin{array}{c}\text { Machaki } \\
\text { Kalan }\end{array}$ & 26.72 & 77.89 & 318.45 & 160.39 & 74.03 & 0.36 & 0.09 & 0.44 \\
\hline 7 & $\begin{array}{c}\text { Mani } \\
\text { Singhwala }\end{array}$ & 26.24 & 71.03 & 301.76 & 148.94 & 68.84 & 0.34 & 0.08 & 0.41 \\
\hline 8 & Gughiana & 24.89 & 68.04 & 299.98 & 143.19 & 66.28 & 0.33 & 0.08 & 0.39 \\
\hline 9 & Sarawan & 40.23 & 64.98 & 401.54 & 161.26 & 75.65 & 0.37 & 0.09 & 0.44 \\
\hline 10 & Muktsar & 41.43 & 78.34 & 434.76 & 183.89 & 85.90 & 0.42 & 0.11 & 0.50 \\
\hline 11 & $\begin{array}{l}\text { Virk } \\
\text { Khera }\end{array}$ & 45.56 & 89.43 & 405.87 & 201.86 & 93.52 & 0.46 & 0.11 & 0.55 \\
\hline 12 & malaout & 33.07 & 86.76 & 411.08 & 185.91 & 86.32 & 0.42 & 0.11 & 0.51 \\
\hline 13 & Jurar & 38.92 & 85.87 & 401.98 & 189.85 & 88.08 & 0.43 & 0.11 & 0.52 \\
\hline 14 & Badal & 39.99 & 70.23 & 401.12 & 168.50 & 78.80 & 0.39 & 0.10 & 0.46 \\
\hline 15 & Giddarbaha & 41.43 & 79.45 & 378.67 & 181.55 & 84.27 & 0.41 & 0.10 & 0.50 \\
\hline 16 & $\begin{array}{c}\text { Abul } \\
\text { Khurana }\end{array}$ & 36.45 & 78.98 & 334.76 & 172.82 & 79.87 & 0.39 & 0.10 & 0.47 \\
\hline 17 & Jandwala & 32.21 & 59.03 & 501.03 & 151.70 & 72.37 & 0.36 & 0.09 & 0.42 \\
\hline 18 & Ferozpur & 42.56 & 102.65 & 289.85 & 209.64 & 95.57 & 0.47 & 0.12 & 0.57 \\
\hline 19 & $\begin{array}{l}\text { Dangar } \\
\text { Khera }\end{array}$ & 42.62 & 68.32 & 387.91 & 167.47 & 78.27 & 0.38 & 0.10 & 0.46 \\
\hline 20 & Balluana & 55.23 & 140.34 & 312.92 & 277.82 & 125.85 & 0.62 & 0.15 & 0.76 \\
\hline 21 & Abohar & 43.72 & 65.98 & 340.23 & 161.89 & 75.35 & 0.37 & 0.09 & 0.44 \\
\hline 22 & Sitoguno & 55.87 & 160.4 & 350.12 & 309.75 & 140.18 & 0.69 & 0.17 & 0.84 \\
\hline 23 & Khubban & 43.81 & 95.89 & 330.84 & 204.09 & 93.63 & 0.46 & 0.11 & 0.56 \\
\hline 24 & Himmatpura & 40.78 & 123.87 & 370.76 & 243.87 & 111.32 & 0.55 & 0.14 & 0.67 \\
\hline 25 & $\begin{array}{c}\text { Radheywala } \\
\text { Chak }\end{array}$ & 45.87 & 110.76 & 330.65 & 227.40 & 103.84 & 0.51 & 0.13 & 0.62 \\
\hline $\max$ & & 55.87 & 160.40 & 501.03 & 309.75 & 140.18 & 0.69 & 0.17 & 0.84 \\
\hline $\min$ & & 23.17 & 59.03 & 228.00 & 136.26 & 62.43 & 0.31 & 0.08 & 0.37 \\
\hline ave & & 37.93 & 84.47 & 351.17 & 183.30 & 84.65 & 0.42 & 0.10 & 0.50 \\
\hline g.m. & & 36.87 & 81.47 & 346.65 & 179.06 & 82.84 & 0.41 & 0.10 & 0.49 \\
\hline
\end{tabular}




\section{Results and discussion}

The measured values for the activity concentration of the natural radionuclides ${ }^{226} \mathrm{Ra},{ }^{232} \mathrm{Th}$ and ${ }^{40} \mathrm{~K}$ together with their average values in soil samples of 25 locations in Punjab (Faridkot, Ferozepur and Muktsar) are reported in table 1. The world average concentration is 35,30 and $400 \mathrm{~Bq} \mathrm{~kg}^{-1}$ for ${ }^{226} \mathrm{Ra},{ }^{232} \mathrm{Th}$ and ${ }^{40} \mathrm{~K}$, respectively. In general, the average activity concentration of ${ }^{226} \mathrm{Ra}$ and ${ }^{232} \mathrm{Th}$ in soil of these areas is higher than the world figures reported in UNSCEAR (2000), whereas the activity for ${ }^{40} \mathrm{~K}$ is under the safe limit. Comparatively high values of ${ }^{226} \mathrm{Ra}$ and ${ }^{232} \mathrm{Th}$ in soil samples from this area may be due to the Punjab sediments that derive from the Shiwalik Himalaya and occur in the form of Alluvium. Residential houses and dwellings in the investigated area were mostly built with bricks made of this soil. There exists information about cancers, average lifetime of people, typical health diseases, etc. in the area very close to the study area (Singh et al., 1995, 2009). To assess the radiological risk of soil used as a building material, it was useful to calculate the radium equivalent activity and external hazard index (Orgun et al., 2005; Beretka and Mathew, 1985). The values of radium equivalent activity $\left(\mathrm{Ra}_{\mathrm{eq}}\right)$ around the investigated areas were less than the acceptable safe limit of $370 \mathrm{~Bq} \mathrm{~kg}^{-1}$ (OECD, 1979). The calculated total absorbed dose and annual effective dose rates of samples are also shown in table 1 .

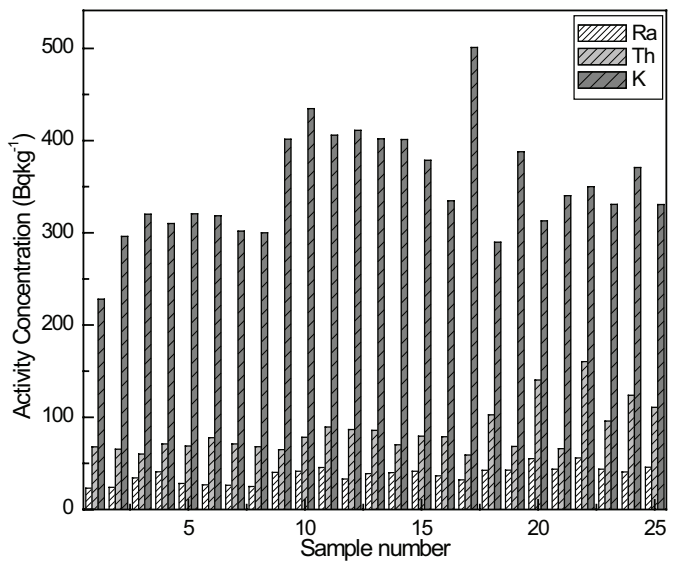

Figure 5: Bar diagram showing the activity concentration of ${ }^{226} \mathrm{Ra},{ }^{232} \mathrm{Th}$ and ${ }^{40} \mathrm{~K}$ at the different sampling sites. 
Table 2: Characteristics of the gamma-ray spectrometer. Equations for elemental counts: Thorium $=C_{3}$, Radium $=C_{2}-a C_{3}$, Potassium $=C_{1}-b C_{3}-c\left(C_{2}-a C_{3}\right)$, where $C_{1}, C_{2}$ and $C_{3}$ are background subtracted true counts in $\mathrm{K}, \mathrm{Ra}$ and $\mathrm{Th}$ energy bands, respectively, $a=0.58, b=0.72, c=1.18$.

\begin{tabular}{|c|c|c|c|}
\hline \multirow{2}{*}{ Parameter } & \multicolumn{3}{|c|}{ For radio nuclides } \\
\cline { 2 - 4 } & ${ }^{226} \mathrm{Ra}$ & ${ }^{232} \mathrm{Th}$ & ${ }^{40} \mathrm{~K}$ \\
\hline Gamma lines used $(\mathrm{MeV})$ & $1.76\left({ }^{214} \mathrm{Bi}\right)$ & $2.62\left({ }^{208} \mathrm{Tl}\right)$ & 1.46 \\
\hline Background reduction factor & 12.3 & 15.4 & 18.5 \\
\hline Percentage efficiency & 1.39 & 1.37 & 4.16 \\
\hline MDA $\left(\mathrm{Bq} \mathrm{kg}^{-1}\right)$ for $120000 \mathrm{~s}$ counting \\
time, $(7.5 \times 6.5)$ cm cylindrical plastic \\
container geometry
\end{tabular}

The calculated total absorbed dose and annual effective dose rates of samples are also shown in table 1. The International Commission on Radiological Protection (ICRP) has recommended the annual effective dose equivalent limit of $1 \mathrm{mSv}^{-1}$ for the individual members of the public and $20 \mathrm{mSv} \mathrm{y}^{-1}$ for the radiation workers (ICRP, 1993). These dose limits have been established on the prudent approach assuming that there is no threshold dose below which there would be no effect. This means that any additional dose would cause a proportional increase in chance of a health effect. The world wide average annual effective dose is approximately $0.5 \mathrm{mSv}$ and the results for individual countries being generally within the $0.3-0.6 \mathrm{mSv}$ range (UNSCEAR, 2000). Table 2 gives the levels of the natural radionuclides in the soil samples of various other countries. When the present data for Punjab are compared to the ones worldwide, it is seen that the overall values of ${ }^{40} \mathrm{~K}$ are in the lower range and the value of ${ }^{226} \mathrm{Ra}$ and ${ }^{232} \mathrm{Th}$ matches with those of the other countries. The highest values of radionuclides recorded (fig. 2) in the soil samples from the investigated area are originating from the Shiwalik Himalaya (composed of radioactive rich granites, sandstones and quartzites) and occur in the form of Alluvium. Plotting the activity of ${ }^{232} \mathrm{Th}$ as function of the ${ }^{40} \mathrm{~K}$ activity of shows a poor correlation $\left(R^{2}=0.03, N=25\right)$ in the soil samples of the investigated area (fig. 3). The calculated values of $H_{\mathrm{ex}}$ for the soil samples range from 0.37 to 0.84 around the investigated area with an average value of 0.50 (table 1 ). 
Table 3: Comparison of natural radioactivity levels in soil at different locations of Punjab (India) with those in other countries as given in UNSCEAR (2000).

\begin{tabular}{|c|c|c|c|c|c|c|}
\hline \multirow[t]{3}{*}{ Region/Country } & \multicolumn{6}{|c|}{ Concentration in soil $\left(\mathrm{Bq} \mathrm{kg}^{-1}\right)$} \\
\hline & \multicolumn{2}{|c|}{${ }^{226} \mathrm{Ra}$} & \multicolumn{2}{|c|}{${ }^{232} \mathrm{Th}$} & \multicolumn{2}{|c|}{${ }^{40} \mathrm{~K}$} \\
\hline & Mean & Range & Mean & Range & Mean & Range \\
\hline Norway & 50 & & 45 & & 850 & \\
\hline Malaysia & 67 & $38-94$ & 82 & $63-110$ & 310 & $170-430$ \\
\hline Egypt & 17 & $5-64$ & 18 & $2-96$ & 320 & $29-650$ \\
\hline US & 40 & $8-160$ & 35 & $4-130$ & 370 & $100-170$ \\
\hline Argentina & & & & & 650 & $540-750$ \\
\hline Bangladesh & 34 & $21-43$ & & & 350 & $130-610$ \\
\hline China & 32 & $2-440$ & 41 & $1-360$ & 440 & $9-1800$ \\
\hline Hongkong & 59 & $20-110$ & 95 & $16-200$ & 530 & $80-1100$ \\
\hline India & 29 & $7-81$ & 64 & $14-160$ & 400 & $38-760$ \\
\hline Japan & 33 & $6-98$ & 28 & $2-88$ & 310 & $15-990$ \\
\hline Thailand & 48 & $11-78$ & 51 & $7-120$ & 230 & $7-712$ \\
\hline Korea,Republic of & - & - & - & - & 670 & $17-1500$ \\
\hline Iran (Islamic Rep. of) & 28 & $8-55$ & 22 & $5-42$ & 640 & $250-980$ \\
\hline Denmark & 17 & $9-29$ & 19 & $8-30$ & 460 & $240-610$ \\
\hline Belgium & 26 & $5-50$ & 27 & $5-50$ & 380 & $70-900$ \\
\hline Luxembourg & 35 & $6-52$ & 50 & $7-70$ & 620 & $80-1800$ \\
\hline Switzerland & 40 & $10-900$ & 25 & $4-70$ & 370 & $40-100$ \\
\hline Bulgaria & 45 & $12-210$ & 30 & $7-160$ & 400 & $40-800$ \\
\hline Poland & 26 & $5-120$ & 21 & $4-77$ & 410 & $110-970$ \\
\hline Romania & 32 & $8-60$ & 28 & $11-75$ & 490 & $250-1100$ \\
\hline Greece & 25 & $1-240$ & 21 & $1-190$ & 360 & $12-1570$ \\
\hline Portugal & 44 & $8-65$ & 51 & $22-100$ & 840 & $220-1230$ \\
\hline Spain & 32 & $6-250$ & 33 & $2-210$ & 470 & $25-1650$ \\
\hline Germany & & $5-200$ & & $7-134$ & & $40-1340$ \\
\hline Hungary & 33 & $14-76$ & 28 & $12-45$ & 370 & $79-570$ \\
\hline Cyprus & 17 & $0-120$ & - & - & 140 & $0-670$ \\
\hline Netherland & 23 & $6-63$ & - & $8-77$ & - & $120-730$ \\
\hline Present Study & 37 & $23-55$ & 59 & $59-160$ & 351 & $228-501$ \\
\hline
\end{tabular}


Since all these values are lower than unity, according to the Radiation Protection report (European Commission, 1999), soil from these regions can be considered as safe and can be used as construction material without posing any significant radiological threat to the population (fig. 4).

\section{Conclusions}

1. The average activity concentration of ${ }^{226} \mathrm{Ra}$ and ${ }^{232} \mathrm{Th}$ in soil of these areas are higher than the world average figures reported in UNSCEAR (2000) whereas the concentration of ${ }^{40} \mathrm{~K}$ is rather low (table 3, fig. 5).

2. High values of ${ }^{226} \mathrm{Ra}$ and ${ }^{232} \mathrm{Th}$ in soil samples from this area may be caused by Punjab sediments originating from the Shiwalik Himalaya. They occur in the form of Alluvium.

\section{Acknowledgments}

The corresponding author Dr. Arvind D. Sabharwal is thankful to the both University Grant Commission (UGC), New Delhi for providing the project in form of Postdoctoral fellowship F.4-2/2006(BSR)/13-270/2008(BSR) and and Education department, Government of Punjab. Dr. Wolfango Plastino, INFN is highly acknowledged for providing the travel grant to attend conference on environmental radioactivity 2010 at Rome, Italy, The residents of the study area for their cooperation during the fieldwork and to the lab staff of G.N.D. University, for their support in providing the necessary equipments for gamma-ray spectrometry.

\section{References}

[1] Beretka J. and Mathew P.J., Natural radioactivity of Australian building materials, industrial wastes and by-products. Health Phys., 48 (1985) 87-95.

[2] International Commission on Radiological Protection (ICRP), ICRP Publication 65, Annals of the ICRP 23(2). (Pergamon Press, Oxford) 1993.

[3] Khan H.M., Khan K., Atta M.A. and Jan F., Measurement of gamma activity of soil samples of Charsadda district of Pakistan. J Chem. Soc. Pakistan, 16 (1994) 183-188. 
[4] Khan K., Khan H.M., Tufail M. and Ahmed N., Radiometric analysis of Hazara phosphate rock and fertilizers. J. Environ. Radioact., 38 (1998) $77-83$.

[5] Menon M.R., Mishra U.C., Lalit B.Y., Shukla V.K. and Ramachandran T.V., Uranium thorium and potassium in Indian rocks and ores, Proceedings of the Indian Academy of Sciences (Earth and Planetary Sciences) 91, (1982) 127-136.

[6] Mollah A.S., Ahmed G.U., Hussain S.R. and Rahman M.M., The natural radioactivity of some building materials used in Bangladesh. Health Phys., 50 (1986) 849-851.

[7] Mehra R., Singh S., Singh K. and Sonkawade R., ${ }^{226} \mathrm{Ra}^{232} \mathrm{Th}$ and ${ }^{40} \mathrm{~K}$ analysis in soil samples from some areas of Malwa region, Punjab, India using gamma ray spectrometry. Environ. Monit. Assess., 134 (2007) 333-342.

[8] Nazaro W.W. and Nero Jr, A.V., In: Radon and its Decay Products in Indoor Air (Wiley, New York) 1988, pp. 57-112.

[9] Nageswara Rao M.V., Natural radioactivity levels in some environmental materials from Rajasthan. Bull. Radiat. Protection, 12 (1989) 36-41.

[10] Organization for Economic Cooperation and Development (OECD), Exposure to radiation from the natural radioactivity in building materials. Report by a Group of Experts of the OECD Nuclear Energy Agency (OECD, Paris, France) 1979.

[11] Orgun Y., Altinsoy N., Gultekin A.H., Karahan G. and Celebi N., Natural radioactivity levels in granitic plutons and groundwaters in Southeast part of Eskisehir, Turkey. Appl. Radiat. Isotop., 63 (2) (2005) 267275 .

[12] Paredes C.H., Kessler W.V., Landolt R.R., Ziemer P.L. and Panstenbach D.J., Radionuclide content of and ${ }^{222} \mathrm{Rn}$ emanation from building materials made from phosphate industry waste products. Health Phys., 53 (1987) 23-29.

[13] Singh J., Singh L. and Singh S., High U-contents observed in some drinking waters of Punjab, India J. Environ. Radioact., 26 (1995) 217222. 
[14] Singh J., Singh H., Singh S., Bajwa B.S. and Sonkawade R.G., Comparative study of natural radioactivity levels in soil samples from the Upper Siwaliks and Punjab, India using gamma-ray spectrometry. $J$. Environ. Radioact., 100 (2009) 94-98.

[15] Turhan S. and Gunduz L., Determination of specific activity of ${ }^{226} \mathrm{Ra}$, ${ }^{232} \mathrm{Th}$ and ${ }^{40} \mathrm{~K}$ for assessment of radiation hazards from Turkish pumice samples, J. Environ. Radioact., 99 (2008) 332-342.

[16] UNSCEAR, Sources and effects of ionizing radiation. United Nations Scientific Committee on the Effects of Atomic Radiation, UN Publication E94.IX.2 (United Nations, New York, USA) 1993.

[17] UNSCEAR, Sources and effects of ionizing radiation United Nation Scientific Committee on the Effects of Atomic Radiation (United Nations, New York) 2000. 